\title{
FAKTOR-FAKTOR YANG MEMPENGARUHI VOLUNTARY AUDITOR SWITCHING (STUDI EMPIRIS PADA PERUSAHAAN NDN FINANCING YANG TERDAFTAR DI BURSA EFEK INDONESIA )
}

\author{
Dame Ria R. Saragi', Audrey M. Siahaan² \\ Fakultas Ekanami dan Bisnis Universitas HKBP Nommensen, Medan \\ damesaragi回uhn.ac.id', audreysiahaan回uhn.ac.id?
}

\section{Info Artikel}

Diterima : 08 Dktober 2020

Revisi : : 13 November 2020

Terbit : : 18 Desember 2020

\section{Key words:}

Auditar Delay, Auditor

Swicthing, Campany Erowth

\begin{abstract}
The phenomenon of Auditor switching has been found to have implications for the credibility of a financial report's value and the monitoring casts of management activities. This study's sample was non-financing companies, which were listed as issuers on the IDX during the 2017-2018 period. Change of Management and company growth together did not affect voluntary Auditor switching. Audit delay does not affect voluntary Auditor switching. The evolution of management daes not affect voluntary Auditor switching. Company growth does not affect voluntary Auditor switching.
\end{abstract}

\begin{tabular}{l}
\hline Abstrak \\
\hline Fenamena Auditar switching telah ditemukan bahwa memiliki implikasi terhadap \\
kredibilitas nilai sebuah laporan keuangan dan biaya monitaring dari aktivitas \\
manajemen. Sampel dalam penelitian ini ialah perusahaan nan financing yang \\
merupakan yang emiten di BEl selama periode 2017-2018. Pertukaran Manajemen, \\
dan pertumbuhan perusahaan secara bersama-sama tidak berpengaruh \\
terhadap voluntary Auditar switching. Audit Delay tidak berpengaruh terhadap \\
voluntary Auditar switching. Pergantian Manajemen tidak berpengaruh terhadap \\
voluntary Auditar switching. Pertumbuhan Perusahaan tidak berpengaruh \\
terhadap voluntary Auditar switching.
\end{tabular}

\section{Kata Kunci:}

Auditor Delay, Auditor

Swicthing, Pertumbuhan

Perusahaan

\section{Corresponding Author :}

Dame Ria, E-mail :

damesaragi|⿴囗玉 


\section{PENDAHULUAN}

Auditor switching adalah pergantian auditor maupun kantor Akuntan Publik (KAP) yang dilakukan oleh perusahaan klien. Auditor switching merupakan salah satu solusi perusahaan untuk mendapatkan kecepercayaan lebih masyarakat dengan menjaga kepercayaan publik dalam fungsi audit dan untuk melindungi objektivitas auditor, melalui serangkaian ketentuan, profesi auditor dilarang memiliki hubngan pribadi dengan klien mereka yang dapat menimbulkan konflik kepentingan sasial. Setiap perusahaan ga public yang terdaftar di Bursa Efek Indonesia wajib menyampaikan laporan keuangan yang telah diaudit oleh auditar independen atau kantor akuntan publik (KAP) kepada pihak internal maupun pihak eksternal. Laporan keuangan merupakan saran komunikasi informasi keuangan utama kepada pihak-pihak di luar perusahaan. Pihak eksternal seperti investor dan pemegang saham memiliki keraguan dengan informasi yang disajikan oleh manajemen karena adanya asimetrs infarmasi antara principa(pemegang saham) dan agent(manajemen). Maka dari itu dibutuhkan auditar sebagai pihak ketiga yang independen dan objektif untuk memeriksa dan menilai kewajaran suatu laparan keuangan. Tujuan audit atas laporan keuangan oleh auditor independen adalah untuk menyatakan pendapat tentang kewajaran mengenai semua hal yang material, pasisi keuangan, hasil usaha, perubahan ekuitas, dan arus kas sesuai dengan akuntansi yang berlaku di Indanesia. Audit dapat meningkatkan nilai suatu laparan keuangan karena melakukan pemeriksaan secara objektif dan memberikan opini atas kewajaran laparan keuangan yang telah disajikan pihak manajemen perusahaan.

Kewajaran informasi dari laparan keuangan yang perlu dilakukan pemeriksaan yang dilakukan oleh auditor independen, di sini auditar dituntut untuk bersifat objektif dan independen terhadap informasi yang disajikan oleh manajemen dalam bentuk laporan keuangan perusahaan. Auditor merupakan pihak ketiga yang independen, auditor bertanggung jawab atas infarmasi yang diberikan kepada investor, walaupun akuntan publik itu sendiri dibayar aleh klien, dalam hal perusahaan

Menurut PSA I (SA 1ID) menyatakan bahwa auditar memiliki tanggung jawab untuk merencanakan dan menjalankan audit untuk memperoleh keyakinan yang memadai mengenai apakah laparan keuangan telah bebas dari salah saji material, yang disebabkan oleh kesalahan atau pun kecurangan, auditar harus mampu mendapatkan keyakinan yang memadai, namun bukan absalute bahwa salah saji material telah dideteksi. Auditor merupakan pihak ketiga yang independen, auditar bertanggung jawab atas infarmasi yang diberikan kepada investar, walaupun akuntan publik itu sendiri dibayar oleh klien.suatu akuntan publik yang bersertifikat atau kantor akuntan publik yang melakukan audit atas entitas keuangan komersial maupun non komersial.

Auditor independen dianggap mampu membuat keputusan yang independen pula, sehingga pihak yang berkepentingan dapat memperoleh informasi keuangan yang dapat dipercaya sebagai dasar pengambilan 
keputusan. Adanya hubungan agensi di antara investar dan perusahaan menyebabkan adanya kebutuhan atas pihak ketiga yang independen, yang tidak berpihak pada agent maupun principal. Keberadaan akuntan publik di sini harus independen karena untuk kepentingan pemberian informasi yang tentu saja mempengaruhi image dari profesi itu sendiri.

Untuk mendapatkan laparan keuangan yang dapat dipercaya maka perusahaan klien diwajibkan untuk melakukan rotasi audit. Rotasi audit adalah peraturan perputaran auditor yang harus dilakukan oleh perusahaan, dengan tujuan untuk menghasilkan kualitas audit yang lebih baik lagi dan menegak kan indepedensi auditor. Di Indanesia ratasi audit diatur dalam peraturan Nomor 20/2015 pasal II yaitu: Fungsi audit dalam menjaga kepercayaan publik dan untuk melindungi abjektivitas auditor, melalui serangkain ketentuan, profesi auditar dilarang memiliki hubungan pribadi dengan klien mereka yang dapat menimbulkan konflik kepentingan potensial. Karena adanya kewajiban rotasi audit tersebut, sehingga timbul perilaku perusahaan untuk melakukan Auditor switching.

Auditor switching merupakan pergantian auditor yang dilakukan oleh perusahaan klien akibat adanya kewajiban rotasi audit. Auditor switching dapat terjadi secara mendatory (wajib) maupun secara voluntary (sukarela), pergantian auditar secara mandatory terjadi jika perusahaan mengganti KAP yang telah mengaudit perusahaan selama masa yang telah ditetapkan maka tidak perlu dipertanyakan lagi, karena hal tersebut bersifat memaksa dan perusahaan melakukan hal ini karena ingin mematuhi peraturan wajib yang telah ditetapkan dan berlaku di Indanesia. Sebaliknya, jika pergantian auditor dilakukan secara voluntary yang dilakukan oleh perusahaan dapat menimbulkan pertanyaan pada pihak-pihak diluar perusahaan terutama investor. Oleh karena itu, menjadi penting untuk diketahui oleh auditor mengenai faktor yang menjadi penyebab klien melakukan pergantian KAP secara voluntary. Manajemen lebih sering mengganti auditornya karen faktor kepercayaan. Manajemen akan memberhentikan auditarnya secara voluntary apabila auditor tersebut tidak dapat memberikan opini yang diharapkan perusahaan dan akan mencari KAP yang selaras dengan kebutuhan perusahaannya. Maka dari itu semakin selaras KAP dengan kebijakan dan pelaparan akuntansi suatu perusahaan maka kecenderungan perusahaan untuk mengganti KAP semakin kecil. Sebaliknya, jika KAP tidak dapat memenuhi tuntunan pertumbuhan perusahaan yang cepat maka kemungkinan besar perusahaan akan mengganti auditor atau KAР-пуа.

Perusahaan dalam melakukan Auditor switching dipengaruhi oleh beberapa faktor antara lain ialah audit delay, pergantian manajemen dan pertumbuhan perusahaan,financial distress, ukuran KAP, persentase RロA, ukuran klien, apini audit, free audit. 
Faktor yang pertama untuk mempengaruhi Auditar switching adalah Audit Delay. Audit delay adalah lamanya waktu yang dibutuhkan auditor untuk mengaudit laparan mengenai kinerja keuangan perusahaan dimulai dari tanggal tutup sampai dengan tanggal opini audit ditandatangani aleh auditor.

Audit delay mempengaruhi perusahaan untuk melakukan Auditar switching. Karena umumnya perusahaan yang mengalami audit delay ditahun sebelumnya berpeluang tinggi untuk melakukan Auditor switching. Audit delay dapat mempengaruhi keputusan investor karena mereka menginginkan infarmasi mengenai keberlangsungan usaha perusahaan untuk keputusan berinvestasi. Perbedaan waktu antara tanggal laparan keuangan dengan tanggal laporan auditor independen mengindikasikan lamanya waktu penyelesaian audit yang dilakukan oleh auditar. Hal ini mengakibat kan informasi akuntansi yang terdapat dalam laparan keuangan terlambat didapat oleh investar. Akibat perusahaan akan terlambat untuk memperoleh tambahan dana guna mendukkung kegiatan operasional. Dalam penelitian Astrini (2013) mengatakan bahwa audit delay tidak berpengaruh terhadap Auditor switching Berbanding terbalik dalam penelitian Pawitri (2015) yang meneliti tentang Auditor switching dengan beberapa variabel independen seperti pergantian manajemen, audit delay, dan opini audit terhadap Auditar switching dimana hasilnya audit delay berpengaruh terhadap Auditar switching. Hal tersebut akan memungkinkan perusahaan mengganti auditarnya, Audit delay bepengaruh terhadap Voluntary Auditor switching.

Faktar kedua untuk mempengaruhi Auditor switching adalah Pergantian Manajemen. Manajemen memiliki peranan penting dalam memilih auditor yang akan memeriksa perusahaannya. Jika manajemen menilai auditar tidak kompeten dalam melaksanakan tugasnya, tentu akan membuat membuat manajemen berpikir untuk melakukan Auditar switching. Pergantian manajemen merupakan pergantian direksi perusahaan yang dapat disebabkan oleh keputusan rapat umum pemegang saham atau berhenti karena kemauannya sendiri pergantian manajemen memungkinkan manajer baru memilih auditor yang memiliki hubungan baik dengan perusahaan ataupun memlih auditor dapat menaati kebijakan-kebijakan dan praktik akuntansi perusahaan. Menurut Nikholas pengertian pergantian manajemen bisa dibagi menjadi tiga, diantaranya : (I) pergantian manajemen yaitu, tugas pengelolaan perubahan yang akan dilakukan, baik itu perubahan yang direncanakan maupun perubahan yang tidak direncanakan; (2) pergantian manajemen yaitu praktek are professional, dimana praktisi dalam bidang manajemen perubahan disebut dengan Agent of change; (3) pergantian manajemen yaitu, suatu ilmu yang didalamnya terdiri dari model, metode, teknik, alat, dan keterampilan, yang kemudian digunakan sebagai dasar dalam praktek perubahan organisasional.

Selain itu perusahaan akan mencari Kantor Akuntan Publik (KAP) yang selaras dengan kebijakan dan pelaparan akuntansinya. Jika hal itu tidak terpenuhi, maka kemungkinan besar perusahaan akan mennganti 
auditornya. Manajemen akan mencari auditor yang dapat sejalan dengan kebijakan-kebijakan dan praktik akuntansi yang manajemen baru terapkan.dalam penelitian Wijaya (2011) yang menyatakan bahwa pergantian manajemen berpengaruh terhadap Auditar switching. Pergantian manajemen berpengaruh terhadap Voluntary Auditor switching.

Faktar ketiga untuk mempengaruhi Auditar switching adalah pertumbuhan perusahaan. Tingkat pertumbuhan perusahaan merupakan hal penting bagi perusahaan karena menjadi salah satu hal yang perlu dipertimbangkan bagi investar untuk membuat keputusan. Pertumbuhan perusahaan diukur dengan tingkat penjualan perusahaan, dimana penjualan ialah aktivitas utama perusahaan, sehingga disaat pertumbuhan perusahaan meningkat, maka perusahaan akan cenderung mempertahankan KAP dibanding ketika pertumbuhan perusahaan rendah. Hal ini disebabkan karena ketika bisnis sedang bertumbuh, permintaan untuk indepensi lebih tinggi dan perusahaan audit yang berkualitas untuk dapat mengurangi biaya keagenan serta memberikan layanan nan-audit yang dibutuhkan untuk meningkatkan perluasan perusahaan. Dalam penelitian Chadegani (20II) menyatakan bahwa pertumbuhan perusahaan tidak berpengaruh terhadap Auditar switching sedangkan dalam penelitian Pawitri (2015) menyatakan bahwa pertumbuhan perusahaan berpengaruh terhadap Auditar switching.

Brigham dan Houstan (2009) menyatakan bahwa pertumbuhan perusahaan adalah perubahan (peningkatan atau penurunan) total asset yang dimiliki perusahaan. Namun dalam melaksanakan tugasnya, auditor umumnya sering menghadapi masalah substansial karena mereka berpegang teguh dengan prinsip profesanalitas tetapi disaat yang sama auditar juga dituntut untuk mengikuti keinginan manajemen. Dalam melakukan audit, searang auditor dituntut untuk dapat melaksanakan tugas-tugas sesuai dengan perilaku akuntan yang telah diatur dalam Kode Etik Akuntan Publik, SPAP dan PSAK. Dalam SPAP auditor diharuskan bersikap independen, yaitu tidak mudah terpengaruh, karena ia melaksanakan pekerjaannya untuk kepentingan umum. Karena dalam melaksanakan proses audit, auditor perlu melakukan pemeriksaan terhadap laporan keuangan dengan harus mempertahankan indepedensi, objektivitas dan integritas. Hubungan yang panjang umumnya dapat menyebabkan auditar memiliki kecenderungan kehilangan indepedensinya, karena semakin tinggi keterikatan auditor dengan klien, semakin tinggi pula kemungkinan auditar membiarkan klien untuk memilih metode akuntansi yang menguntungkan bagi perusahaan. Pemerintah Indanesia mengeluarkan regulasi dalam Keputusan Menteri Keuangan Nomor 423/KMK.06/2002 yang kemudian diubah dengan keputusan Menteri Keuangan Nomor 359/KMK.06/2003 adalah tentang 'Jasa Akuntan Publik' ( pasal 6). Peraturan ini menyebutkan bahwa tentang pemberian jasa audit umum atas laparan keuangan pada sebuah perusahaan yang dilakukan oleh KAP (Kantor Akuntan Publik) paling lama yaitu 5 tahun buku berturut-turut dan oleh searang akuntan publik 
paling lama untuk 3 tahun berturut-turut. Peraturan tersebut kemudian diperbaharui dengan Peraturan Menteri Keuangan Nomar 17/PMK.0l/2008 tentang'Jasa Akuntan Publik' (pasal 3 ayat I) yang berisi tentang pemberian jasa audit umum atas laparan keuangan dari suatu entitas paling lama 6 tahun buku berturut-turut dan oleh searang akuntan public paling lama 3 tahun berturut-turut. Lalu pada (pasal 3 ayat 2) berisi tentang bahwa KAP dan akuntan publik boleh menerima kembali penugasan setelah satu tahun buku tidak memberikan jasa audit kepada klien yang diatas.

Tingkat pertumbuhan perusahaan yang semakin tinggi, membutuhkan KAP yang mampu memenuhi perusahaan. jika KAP tersebut tidak memenuhi kebutuhan perusahaan, maka perusahaan kemungkinan akan mengganti KAP. Hasil penelitian dari Wijaya menyatakan bahwa pertumbuhan perusahaan berpengaruh signifikan terhadap pergantian auditor.

Fenomena Auditar switching telah ditemukan bahwa memiliki implikasi terhadap kredibilitas nilai sebuah laporan keuangan dan biaya monitoring dari aktivitas manajemen. Suatu perusahaan bebas untuk memilih auditor mereka sendiri namun perusahaan tersebut harus memahami faktor-faktor apa saja yang nantinya akan mempengaruhi pilihan atas auditor dan keputusan untuk mengganti auditor. Penelitian ini adalah replikasi dari penelitian Pawitri (2015) meneliti tentang hubungan Auditor switching dengan beberapa variabel independen seperti pergantian manajemen, audit delay, opini audit, dan reputasi audit terhadap voluntary Auditor switching. Perbedaan penelitian ini dengan peneliti sebelumnya adalah, dalam peneliti ini variabel yang dipake hanya 3 varibel yaitu audit delay, pergantian manajemen dan pertumbuhan perusahaan. selanjutnya peneliti mengambil sampel tahun 2017-2018. Dengan alasan untuk melihat gambaran hasil dari jumlah sampel yang berbeda dari peneliti terdahulu dan untuk menemukan informasi tentang perusahaan yang melakukan Auditor switching.

. Fenomena mengenai pergantian KAP secara voluntary banyak dilakukan oleh perusahaan di indonesia. Hal ini dibuktikan dengan adanya data yang menunjukan bahwa banyak perusahaan yang Auditar switching yaitu sebanyak 36 perusahaan yang diteliti selama periode tahun 2017-2018 dalam perusahaan nan financing yang terdaftar di Bursa Efek Indanesia.

Fenomena lainnya masih ada beberapa perusahaan yang melakuakan Auditor switching diluar ketentuan undang-undang (voluntary Auditor switching).

Fenomena mengenai pergantian auditor ini menarik untuk diteliti karena banyak nya faktor yang dapat mempengaruhi perusahaan untuk melakukan Auditar switching. Dalam penelitian ini, peneliti hanya memilih tiga variabel independen saja yaitu aduit delay, pergantian manajemen, dan pertumbuhan perusahaan. 
Bagi investar, penelitian ini dapat dijadikan bahan pertimbangan dan masukan untuk menilai kinerja perusahaan sehingga membantu dalam pengambilan keputusan, dapat memberikan pandangan dan wawasan terhadap pengembangan pengauditan khususnya auditor switching secara voluntary. Serta, pemahaman mengenai faktor-faktor yang mempengaruhi auditar switching secara voluntary pada prusahaan non financing yang terdaftar di BEl.

\section{METDDE PENELITIAN}

Penelitian ini bertujuan untuk menguji aengaruh audit delay, pergantian manajemen, dan pertumbuhan perusahaan terhadap Auditor switching melalui hypothesis testing ( pengujian hipotesis). Sebagaimana tujuan penelitian, maka jenis dari penelitian ini ialah penelitian verifikatif.

Populasi pada penelitian ini ialah beberapa perusahaan non financing yang terdaftar secara berturutturut di BEI 2017-2018. Sampel dalam penelitian ini ialah perusahaan non financing yang merupakan yang emiten di BEl selama periode 2017-2018.

Sampel dalam penelitian ini ialah perusahaan non financing yang merupakan yang emiten di BEl selama periode 2017-2018. Teknik analisis yang digunakan dalam penelitian ini ialah analisis regresi logistic. Analisis regresi logistik dipilih sebagai metode analisis penelitian ini karena data yang digunakan bersifat non meltik pada variabel dependen.

\section{Definisi Dperasional}

Dalam penelitian ini variabel dependen yang diteliti oleh si peneliti adalah auditor switching. Variabel auditar switching ini menggunakan variabel dummy, daan hanya ada 2 kemungkinan yaitu : terjadi auditor switching atau tidak. Variabel independen yang digunakan dalam penelitian ini ialah sebagai berikut: audit delay, pergantian manajemen, dan pertumbuhan perusahaan.

Definisi operasional dari auditor Switching adalah pilihan dilakukan manajer menentukan kebijakan akuntansi untuk mencapai tujuan tertentu (Scott, 2006). Definisi auditar delay adalah olah hari dari tanggal tutup buku tahun perusahan 31 Desember sampai tanggal ditandatanganinya laparan audit. Definisi aperasional dari pergantian manajemen adalah komite audit pada perusahaan publik Indanesia terdiri dari setidaknya 3 orang anggata dan diketahiu oleh komisaris independen perusahaan dengan Zorang eksternal yang independen.

\section{HASIL DAN PEMBAHASAN}

Pengujian dalam penelitian ini bertujuan untuk menguji pengaruh audit delay, pergantian manajemen, pertumbuhan perusahaan terhadap voluntary Auditar switching dengan menggunakan analisis regresi logistik. 
Analisis regresi logistik ini digunakan untuk mendapatkan nilai-nilai knefisien logit dengan koefisien determinasi yang sesungguhnya.

\begin{tabular}{|c|c|c|}
\hline \multicolumn{3}{|c|}{ Iteration History ${ }^{\mathrm{a}, \mathrm{b}, \mathrm{c}}$} \\
\hline \multirow[t]{2}{*}{ Iteration } & \multirow{2}{*}{-2 Log likelihoud } & Coefficients \\
\hline & & Constant \\
\hline \multirow{3}{*}{ Step 0} & 86,967 & -.833 \\
\hline & 86,924 &,- 887 \\
\hline & 80,924 & -.887 \\
\hline \multicolumn{3}{|c|}{$\begin{array}{l}\text { a. Constant is included in the model. } \\
\text { b. Initial -2 Log Likelihnod: 86,924 } \\
\text { c. Estimation terminated at iteration number } 3 \text { because } \\
\text { parameter estimates changed by less than ,0Dl. }\end{array}$} \\
\hline
\end{tabular}

Untuk variabel Berganti KAP tidak dimasukan karena variabel tersebut adalah variabel Dummy.

Berdasarkan hasil dari table Interation Histary pada block 0 maka didapatkan nilai -2 Log Likelihad untuk Audit Delay, Pergantian Manajemen Dan Pertumbuhan Perusahaan adalah sebesar 86,924 dengan Degree of Fredam $(\mathrm{dF})=\mathrm{N}-\mathrm{Z}=72$ - 2 = 70. Maka, pada table dF 70 dengan probabilitas 0.05 nilai Chi-Square adalah sebesar 90,53l Untuk penentuan keputusan FIT atau TIDAK FIT, Nilai -2 Log Likelihood (86,924) < X2 tabel (90,531) sehingga menerima $\mathrm{H}_{\square}$, maka menunjukkan bahwa model sebelum memasukkan variabel independen adalah FIT dengan data

Di atas pada tabel 3 Iteration histary Black I atau saat variabel independen dimasukkan dalam model: N=72. Degree of Freedam (DF) = N - jumlah variabel independen -1 = 72-3-1=68. Chi-Square Tabel, pada DF 68 dan Prob 0.05 = 88,250. Nilai -2 Log Likelihood (72,491) < Chi-Square tabel (88,250) sehingga menerima HD, maka menunjukkan bahwa madel dengan memasukkan variabel independen adalah FIT dengan data. Hal ini serupa dengan Black Beginning di atas, di mana saat sebelum variabel independen dimasukkan ke dalam madel, madel FIT dengan data.

Pada tabel 3, dengan memperhatikan nilai signifikansi sebesar 0,002 (< 0,05) sehingga menalak HD, yang menunjukkan bahwa penambahan variabel independen AKAN memberikan pengaruh nyata terhadap madel, atau dengan kata lain model dinyatakan FIT.

Hosmer and Lemeshow Test adalah uji Gaodness of fit test (GaF), yaitu uji untuk menentukan apakah model yang dibentuk sudah tepat atau tidak. Dikatakan tepat apabila tidak ada perbedaan signifikan antara madel dengan nilai observasinya. Nilai Chi Square tabel untuk DF 3 (Jumlah sampel dari variabel independen, yaitu 3) pada taraf signifikansi 0,05 adalah sebesar 0,071 atau dengan kata lain bahwa nilai signifikansi sebesar 0,071 (> 
0,05) sehingga menerima HD, yang menunjukkan bahwa madel DAPAT diterima dan pengujian hipatesis dapat dilakukan sebab ada perbedaan signifikan antara model dengan nilai observasinya.

Tabel 2. Hasil Pengujian Keseluruhan Variabel Dengan Regresi Logistik Memakai Iteration History

\begin{tabular}{|c|c|c|c|c|c|c|}
\hline \multicolumn{7}{|c|}{ Iteration History ${ }^{\mathrm{a}, \mathrm{b}, \mathrm{c}, \mathrm{d}}$} \\
\hline \multirow[t]{2}{*}{ Iteratio } & & \multirow[t]{2}{*}{-2 Log likelihand } & \multicolumn{4}{|c|}{ Coefficients } \\
\hline & & & Constant & $\mathrm{XI}$ & $x 2$ & $X 3$ \\
\hline \multirow{20}{*}{ Step I } & I & 75,081 & $-1,027$ & 2,927 & 480 & , \\
\hline & 2 & 73,247 & $-1,117$ & 4,150 & .641 & , \\
\hline & 3 & 72,663 & $-1,094$ & 5.190 & .691 & , \\
\hline & 4 & 72,536 & $-1,083$ & 6,206 & .713 & , \\
\hline & 5 & 72,507 & $-1,082$ & 7,212 & .716 & , 000 \\
\hline & 6 & 72,497 & $-1,082$ & 8,214 & .716 & , प0 \\
\hline & 7 & 72,493 & $-1,082$ & 9,215 & .716 & (0) \\
\hline & 8 & 72,491 & $-1,082$ & 10,215 & .716 & , \\
\hline & g & 72.491 & $-1,082$ & 11,215 & .716 & , \\
\hline & 10 & 72,491 & $-1,082$ & 12,215 & .716 & , \\
\hline & $\|$ & 72,491 & $-1,082$ & 13,215 & .716 & , \\
\hline & 12 & 72,491 & $-1,082$ & 14,215 & .716 & , \\
\hline & 13 & 72,491 & $-1,082$ & 15,215 & .716 & , 00[ \\
\hline & 14 & 72,491 & $-1,082$ & 16,215 & .716 & , \\
\hline & 15 & 72,491 & $-1,082$ & 17,215 & .716 & (0) \\
\hline & I6 & 72,491 & $-1,082$ & 18,215 & .716 & , 000 \\
\hline & 17 & 72,491 & $-1,082$ & 19,215 & .716 & , प्रा \\
\hline & 18 & 72,491 & $-1,082$ & 20,215 & .716 & , \\
\hline & 19 & 72,491 & $-1,082$ & 21,215 & .716 & , प्र \\
\hline & 20 & 72,491 & $-1,082$ & 22,215 & .716 & (0), \\
\hline \multicolumn{7}{|c|}{$\begin{array}{l}\text { a. Methad: Enter } \\
\text { b. Constant is included in the model. } \\
\text { c. Initial }-2 \text { Log Likelihodd: 86,924 } \\
\text { d. Estimation terminated at iteration number } 20 \text { because maximum iterations has been reached. Final } \\
\text { solution cannot be found. }\end{array}$} \\
\hline
\end{tabular}

Tabel 3. Hasil Pengujian Keseluruhan Variabel Dengan Dmnibus Test

\begin{tabular}{|c|c|c|c|c|}
\hline \multicolumn{5}{|c|}{ Omnibus Tests of Model Coefficients } \\
\hline & & Chi-square & $d f$ & Sig. \\
\hline \multirow{3}{*}{ Step 1} & Step & 14,433 & 3 & 002 \\
\hline & Block & 14,433 & 3 &, 002 \\
\hline & Model & 14,433 & 3 & , 002 \\
\hline
\end{tabular}

Faktor-faktor yang Mempengaruhi Voluntary Auditar switching (Studi Empiris pada perusahaan Non Financing yang I erdaftar di Bursa Efek Indanesia ) 
Pada hasil pengujian di atas pada tabel Variables in The Equation. Saat setelah variabel independen di masukkan ke dalam madel, maka telah memasukkan Dummy pada variabel terikat ke dalam madel yang digunakan. Nilai Slope atau Koefisien Beta (B) dari Konstanta yaitu Berganti KAP adalah sebesar -1,082 dan untuk Variabel Bebas pada XI yaitu Audit Delay adalah sebesar 22,215, pada XZ yaitu Pergantian Manajemen adalah sebesar 0,716 serta X3 yaitu Pertumbuhan Perusahaan adalah sebesar Q,00. dengan Odds Ratio atau Exp(B) pada tiap variabel secara berurutan adalah Y sebesar 0,339 pada XI sebesar 4446481411,240 untuk XZ sebesar 2,046 dan X3 sebesar I,000. Nilai Signifikansi atau p value dari uji Wald sebesar 0,002 pada Variabel Switching, 0,999 pada variabel Audit Delay, 0,253 pada variabel Pergantian Manajemen dan 0,260 pada variabel Pertumbuhan Perusahaan.

Tabel 4 Hasil Pengujian Keseluruhan

\begin{tabular}{|c|c|c|c|c|c|c|c|c|c|}
\hline \multicolumn{10}{|c|}{ Variables in the Equation } \\
\hline & & \multirow[t]{2}{*}{ B } & \multirow[t]{2}{*}{ S.E. } & \multirow[t]{2}{*}{ Wald } & \multirow[t]{2}{*}{$\mathrm{df}$} & \multirow[t]{2}{*}{ Sig. } & \multirow[t]{2}{*}{$\operatorname{Exp}(B)$} & \multicolumn{2}{|c|}{ 95\% С.I.for EXP(B) } \\
\hline & & & & & & & & Lower & Uррег \\
\hline \multirow{4}{*}{ Step $\left.\right|^{\mathrm{a}}$} & $X I$ & 22,215 & 19973,341 & , प्र० & 1 &, 999 & 4446481411,240 & , प00 & \\
\hline & $x Z$ & .716 & ,627 & 1,304 & 1 & 253 & 2,046 & .599 & 6,991 \\
\hline & $X 3$ & 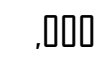 & , & 1,271 & 1 & ,260 & 1,000 & 1,000 & 1,000 \\
\hline & Constant & $-1,082$ & 358 & 9,163 & 1 & , 002 & 339 & & \\
\hline
\end{tabular}

a. Variable(s) entered on step I: XI, XZ, X3.

Pada hasil pengujian di atas pada tabel Variables in The Equation. Saat setelah variabel independen di masukkan ke dalam madel, maka telah memasukkan Dummy pada variabel terikat ke dalam madel yang digunakan. Nilai Slope atau Kaefisien Beta (B) dari Konstanta yaitu Berganti KAP adalah sebesar -I,Z8Z dan untuk Variabel Bebas pada XI yaitu Audit Delay adalah sebesar 2Z,Z15, pada XZ yaitu Pergantian Manajemen adalah sebesar 0,716 serta X3 yaitu Pertumbuhan Perusahaan adalah sebesar 0,00. dengan Odds Ratio atau Exp(B) pada tiap variabel secara berurutan adalah Y sebesar 0,339 pada XI sebesar 4446481411,240 untuk XZ sebesar 2,046 dan X3 sebesar 1,000. Nilai Signifikansi atau p value dari uji Wald sebesar Q,002 pada Variabel Switching, 0,999 pada variabel Audit Delay, 0,253 pada variabel Pergantian Manajemen dan 0,260 pada variabel Pertumbuhan Perusahaan.

Hasil hipatesis penelitian ini ditalak, dimana hasil penelitian ini mengatakan bahwa audit delay, pergantian manajemen, dan pertumbuhan perusahaan tidak berpengaruh kepada auditor switching. Ini sesuai 
dengan penelitian dari Astrini (2013) dan Chadegani (2011). Tetapi hasil penelitian ini tidak sesuai dengan hasil penelitian dari Khasharmeh (2015) dan Wijaya (2011) yang mengatakan bahwa pergantian manajemen berpengaruh negative terhadap auditor Switching. Pawitri (2015) mengatakan bahwa audit delay dan pergantian manajemen mempengaruhi auditor switching, sehingga penelitian Pawitri tidak sesuai dengan hasil penelitian saya.

\section{KESIMPULAN}

Audit delay, pergantian manajemen, dan pertumbuhan perusahaan secara bersama-sama tidak berpengaruh terhadap voluntary auditor switching pada perusahaan non financing yang terdaftar di Bursa Efek Indanesia tahun 2017-2018. Audit Delay tidak berpengaruh terhadap voluntary Auditar switching pada perusahaan non financing yang terdaftar di Bursa Efek Indanesia tahun 2017-2018. Pergantian Manajemen tidak berpengaruh terhadap voluntary Auditor switching pada perusahaan non financing yang terdaftar di Bursa Efek Indanesia tahun 2017-2018. Pertumbuhan Perusahaan tidak berpengaruh terhadap voluntary Auditar switching pada perusahaan nan financing yang terdaftar di Bursa Efek Indanesia tahun 2017-2018 


\section{DAFTAR PUSTAKA}

Brigham dan Houston(2009), "Pengaruh Pertumbuhan Perusahaan , ukuran KAP dalam Auditar switching". Jurnal Penelitian hal I0

r Switching", Universitas Stikubank, Semarang, 2018, hal 4

Mardiyah, A.A, "Pengaruh Faktar Klien dan Faktar Auditar terhadap Auditar Lhanges: Sebuah pendekatan dengan Made/ Kantijensi RPA". Simposium Nasional Akuntansi V. Semarang.

Pawitri, Ni Made, Yandyana, K 2015, "Pengaruh Audit Delay, Dpini Audit, Reputasi Auditor dan Pergantian Manajemen Valuntary Auditar switching". Skripsi jurusan Akuntansi Fakultas Ekanami dan Universitas Udayana

PSA I(SA IIC), "Jasa Audit dan Assurance pendekatan Terpadu (Adaptasi Indanesia)". Buku I Penerbit Salemba Empat, Jakarta, 2011. Hal I05b

Peraturan Pemerintah Indonesia Tahun 2015, "Peraturan Jasa akuntan publik, E-Jaurnal, Pernyataan Standar Akuntansi.

Subekti, Skripsi, "Pengaruh audit Delay, Dpini Audit, Pertumbuhan Perusahaan". Universitas udayana

Subekti, Imam dan Novi Wulandari Widiyanti, "Faktar-faktor yang Berpengaruh Terhadap Audit Delay Di Indanesia". SNA VII Denpasar Bali.

Teari keagenan menurut Jensen dan Meckling dalam skripsi jonni, "Pengaruh Audit Tenura, Reputasi Auditar, Disclasure, dan apini Gaing Lancern". 